Jurnal Kirana 2020 Vol. 1(1): 31-45

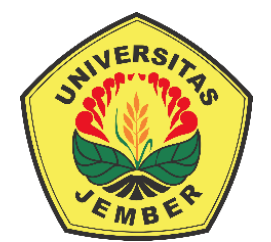

Jurnal Komunikasi dan Penyuluhan Pertanian Journal of Communication and Agricultural Extension

email: jurnalkirana@unej.ac.id

https://jurnal.unej.ac.id/index.php/jkrn

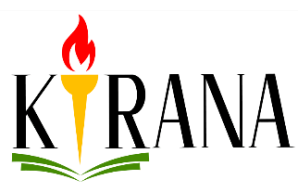

Jurnal Komunikasi dan Penyuluhan Pertarian

\title{
Pemberdayaan Peternak Sapi Potong Menuju Kemandirian
}

\section{Empowerment of Beef Cattle Farmers for Selfrelience}

\section{Lany Sonia Wulandari ${ }^{1 凶}$ dan Sri Subekti²}

${ }^{1}$ Program Studi Agribisnis Fakultas Pertanian Universitas Jember

2 Program Studi Penyuluhan Pertanian Fakultas Pertanian Universitas Jember

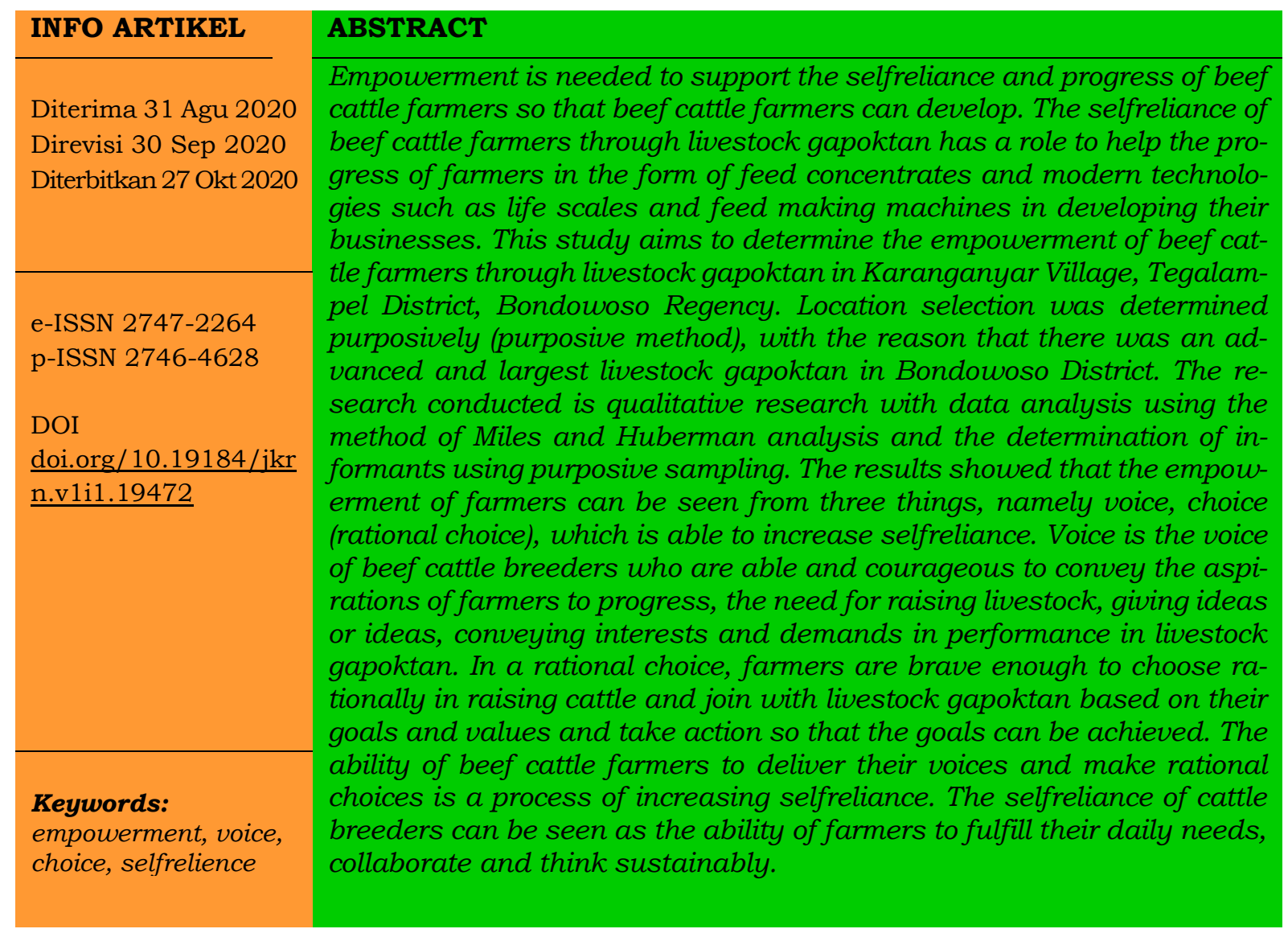

凶 Penulis Koresponden :

E-mail : 1swlany@gmail.com 


\begin{tabular}{|c|c|}
\hline & ABSTRAK \\
\hline $\begin{array}{l}\text { Kata kunci: } \\
\text { pemberdayaan, voice, } \\
\text { choice, kemandirian }\end{array}$ & $\begin{array}{l}\text { Pemberdayaan dibutuhkan untuk mendukung kemandirian dan kema- } \\
\text { juan peternak sapi potong agar peternak sapi potong dapat berkem- } \\
\text { bang. Kemandirian peternak sapi potong melalui gapoktan ternak } \\
\text { yang berperan untuk membantu kemajuan peternak berupa pakan } \\
\text { konsentrat serta teknologi modern seperti alat timbang hidup dan me- } \\
\text { sin pembuat pakan dalam mengembangkan usahanya. Penelitian ini } \\
\text { bertujuan untuk mengetahui pemberdayaan pada peternak sapi } \\
\text { potong melalui gapoktan ternak di Desa Karanganyar Kecamatan Te- } \\
\text { galampel Kabupaten Bondowoso. Pemilihan lokasi ditentukan secara } \\
\text { sengaja (purposive methode), dengan alasan terdapat gapoktan ternak } \\
\text { yang maju dan terbesar di Kabupaten Bondowoso. Penelitian yang dil- } \\
\text { akukan merupakan penelitian kualitatif dengan Analisis data } \\
\text { menggunakan metode analisis Miles and Huberman dan penentuan } \\
\text { informan menggunakan purposive sampling. Hasil penelitian menun- } \\
\text { jukan bahwa pemberdayaan peternak dapat dilihat dari tiga hal yaitu } \\
\text { voice, choice (pilihan rasional), yang mampu meningkatkan ke- } \\
\text { mandirian. Voice merupakan suara peternak sapi potong yang mampu } \\
\text { dan berani menyampaikan aspirasi peternak untuk maju, kebutuhan } \\
\text { dalam beternak, memberikan ide atau gagasan, menyampaikan } \\
\text { kepentingan dan tuntutan dalam kinerja di gapoktan ternak. Pada pili- } \\
\text { han rasional yaitu peternak berani memilih secara rasional dalam be- } \\
\text { ternak sapi dan bergabung dengan gapoktan ternak berdasarkan } \\
\text { tujuan dan nilai serta melakukan tindakan agar tujuan dapat tercapai. } \\
\text { Kemampuan peternak sapi potong dalam menyampaikan suara dan } \\
\text { melakukan pilihan rasional merupakan proses peningkatan ke- } \\
\text { mandirian. Kemandirian peternak sapi dapat dilihat kemampuan pe- } \\
\text { ternak untuk memenuhi kebutuhan hidup, melakukan kerjasama, dan } \\
\text { berpikir secara berkelanjutan. } \\
\text { C) } 2020, \text { PS Penyuluhan Pertanian UNEJ }\end{array}$ \\
\hline
\end{tabular}

\section{PENDAHULUAN}

Menurut Anggita (2013), pertanian secara sempit dapat diartikan sebagai proses budidaya tanaman pada suatu lahan yang hasilnya dapat mencukupi kebutuhan manusia atau proses bercocok tanam yang dilakukan di lahan yang telah disiapkan sebelumnya dan dikelola menggunakan cara manual tanpa terlalu banyak menggunakan manajemen. Pertanian dalam arti luas meliputi pertanian dalam arti sempit yaitu perikanan, kehutanan dan peternakan. Peternakan merupakan potensi dalam pembangunan yang memiliki prospek yang baik dimasa yang akan datang karena produk yang berasal dari ternak akan terus meningkat seiring dengan permintaan jumlah penduduk, pendapatan dan kesadaran masyarakat untuk mengkonsumsi pangan bergizi tinggi sebagai pengaruh dari naiknya tingkat pendidikan. Pengembangan usaha ternak ditujukan untuk meningkatkan ketahanan pangan dan meningkatkan daya beli masyarakat melalui perbaikan pendapatan.

Pulau Jawa menjadi salah satu daerah sentra ternak sapi potong dengan tiga provinsi ternak sapi potong terbesar di Indonesia yaitu, Jawa Timur, Jawa Barat, dan Jawa Tengah. Provinsi Jawa Timur merupakan daerah penyangga ternak sapi potong terbesar nasional, sehingga wilayah ini disamping mampu memenuhi sendiri kebutuhan konsumsi daging ternak, juga mampu mensuplai ternak hidup dan daging segar ke beberapa wilayah di Indonesia. Provinsi Jawa 
Timur memiliki potensi besar untuk pengembangan sapi potong. Keberadaan sapi potong yang ada di Jawa Timur dapat mempengaruhi produksi daging sapi di Indonesia yang membuat produksi daging sapi berkurang.

Program swasembada daging sapi sebagai upaya penyediaan gizi bagi masyarakat, masih mengalami berbagai kendala antara lain pengetahuan peternak tentang cara beternak sapi yang baik agar memperoleh hasil produksi yang maksimal, adanya orang ketiga sebagai perantara penjualan sapi yang memberikan harga rendah dan ketergantungan musim untuk pakan sapi. Pemberdayaan peternak sapi sangat diperlukan untuk memberdayakan diri dan pengembangan peternak menjadi lebih baik dalam beternak sapi. Menurut Firmansyah (2012), pemberdayaan masyarakat adalah sebuah konsep pembangunan yang merangkum multi-aspek. Salah satu perwujudan dari pemberdayaan masyarakat adalah adanya suatu program yang dapat meningkatkan daya masyarakat dan melalui proses pendekatan terhadap masyarakat, keinginan masyarakat untuk meningkatkan daya diri sendiri dan memanfaatkan potensi yang ada dilingkungannya agar berkesinambungan.

Pengembangan ternak sapi tentunya tidak terlepas dari peranan kelompok tani ternak dalam mengupayakan ternaknya agar mendapat nilai tambah serta efisien dalam pengelolaannya. Salah satu desa yang menyumbang populasi sapi potong di Bondowoso adalah Desa Karanganyar yang memiliki gabungan kelompok tani ternak untuk pemberdayaan. Gabungan Kelompok tani ternak tersebut merupakan gapoktan ternak yang maju. Hal tersebut dapat dilihat dari jumlah anggota dan teknologi yang digunakan gapoktan ternak Mitra Subur yaitu teknologi modern, seperti alat timbang hidup dan mesin pembuat pakan. Peternak sapi potong yang bergabung dengan gapoktan ternak tidak lagi menggunakan pakan rumput melainkan pakan konsentrat sehingga peternak tidak mengalami kesulitan saat musim kemarau. Dalam pemberdayaan peternak sapi potong gabungan kelompok tani ternak bekerjasama dengan beberapa intansi yaitu Dinas Peternakan Kabupaten Bondowoso, BI (Bank Indonesia), dan PT Bolo Farm Lumajang. Berdasarkan hal tersebut peneliti ingin melihat bagaimana pemberdayaan peternak sapi potong melalui gabungan kelompok Tani Ternak Mitra Subur Satu di Desa Karanganyar Kecamatan Tegalampel Kabupaten Bondowoso.

\section{METODE PENELITIAN}

Penentuan daerah penelitian ini dilakukan purposive method (secara sengaja). Daerah penelitian yang dipilih berada di Desa Karanganyar Kecamatan Tegalampel Kabupaten Bondowoso. Alasan pemilihan lokasi adalah Bondowoso merupakan penyumbang daging sapi di Jawa Timur dan memiliki gabungan kelompok tani ternak sapi yang maju dengan menggunakan pakan sapi konsentrat sebagai pengganti rumput dan memiliki teknologi modern seperti alat timbang hidup dan mesin pembuat konsentrat.

Metode dalam penelitian ini menggunakan metode deskriptif kualitif. Menurut Sugiyono (2014), penelitian kualitatif digunakan untuk meneliti pada kondisi obyek yang alamiah dan hasil penelitian lebih menekankan makna. Penelitian ini menggunakan pendekatan deskriptif kualitatif dengan tujuan untuk memberikan gambaran atau lukisan secara sistematis, faktual, dan akurat 
mengenai fakta-fakta, sifat-sifat serta hubungan antar fenomena yang diselidiki terkait dengan pemberdayaan peternak sapi melalui gabungan kelompok tani ternak di Desa Karanganyar Kecamatan Tegalampel Kabupaten Bondowoso.

Metode penentuan informan yang digunakan adalah purposive sampling. Menurut Sugiyono (2014), purposive sampling adalah teknik pengambilan sampel sumber data dengan pertimbangan tertentu. Pertimbangan tertentu ini, misalnya orang tersebut yang dianggap paling tahu tentang apa yang kita harapkan, atau mungkin dia sebagai penguasa sehingga akan memudahkan peneliti menjelajahi obyek/situasi sosial yang diteliti. Kriteria informan pada penelitian ini terdiri dari orang yang terlibat dalam kegiatan kelompok tani ternak, peternak sapi yang tergabung dalam gapoktan ternak, peternak yang aktif didalam gapoktan ternak dan peternak yang memiliki waktu memadai untuk dimulai informasi.

Metode pengumpulan data pada penelitian ini yaitu wawancara, observasi dan dokumentasi. Wawancara yang dilakukan adalah wawancara mendalam yang dilakukan dengan percakapan dua arah dalam suasana kesetaraan, akrab dan informal. Data yang diperoleh dengan wawancara mendalam tersebut meliputi data identitas informan dan aktivitas-aktivitas peternak didalam gapoktan ternak. Observasi adalah bagian dalam pengumpulan data. Observasi berarti mengumpulkan data langsung dari lapangan (Semiawan, 2010). Observasi yang dilakukan partisipasi pasif dimana peneliti terjun langsung ke lapang namun, tidak terlibat dalam kegiatan tersebut. Penggunaan metode observasi untuk melihat langsung proses pemeliharaan dan pembuatan pakan di gapoktan ternak. Metode pengumpulan data menggunakan dokumentasi dengan maksud untuk memperoleh data pelengkap dari penggunaan metode wawancara dan observasi. Metode pengumpulan data menggunakan dokumentasi dengan maksud untuk memperoleh data pelengkap dari penggunaan metode wawancara dan observasi. Tujuan penggunaan metode studi dokumentasi adalah untuk memperoleh informasi terkait profil Desa Karanganyar, profil peternak sapi potong, dan foto didalam kegiatan gapoktan ternak.

Metode analisis data yang digunakan dalam penelitian adalah model Miles dan Huberman Model Miles dan Huberman digunakan untuk menyelesaikan permasalahan mengenai pemberdayaan peternak sapi potong melalui Kelompok tani ternak di Desa Karanganyar Kecamatan Tegalampel Kabupaten Bondowoso. Menurut Afrizal (2014), model Miles dan Huberman membagi analisis data dalam penelitian kualitatif ke dalam tiga tahap, yaitu kodifikasi data, penyajian data, dan penarikan kesimpulan/verifikasi.

\section{HASIL DAN PEMBAHASAN}

\section{Pemberdayaan Peternak Sapi Potong Melalui Gabungan Kelompok Tani Ternak di Desa Karanganyar Kecamatan Tegalampel Kabupaten Bondowoso.}

Menurut Word Bank dalam Mardikanto \& Soebianto, (2012), mengartikan pemberdayaan sebagai upaya untuk memberikan kesempatan dan kemampuan kepada kelompok masyarakat (miskin) untuk mampu dan berani bersuara (voice) atau menyuarakan pendapat, ide, atau gagasan-gagasannya, serta kemampuan dan keberanian untuk memilih (choice) sesuatu (konsep, metoda, produk, tindakan dan lain-lain) yang terbaik bagi pribadi, keluarga, dan masyarakat 
merupakan proses meningkatkan kemampuan dan sikap kemandirian masyarakat. Pemberdayaan pada peternak sapi potong dapat dilihat dari voice, choice, dan kemandirian.

a. Voice (Suara) Peternak Sapi Potong di dalam Gapoktan ternak

Menurut Mulyawan (2016), Voice adalah hak dan tindakan warga masyarakat menyampaikan aspirasi, gagasan, kebutuhan, kepentingan dan tuntutan terhadap komunitas terdekatnya maupun kebijakan pemerintah. Voice (suara) peternak sapi potong di Desa Karanganyar Kecamatan Tegalampel Kabupaten Bondowoso dapat dilihat dari hasil wawancara yang dilakukan peneliti dan infoman mengenai perihal apa saja yang telah disampaikan oleh peternak. Pada wawancara yang telah dilakukan, peneliti menemukan hal-hal yang ada dalam penjelasan Word Bank yaitu tindakan peternak dalam meyampaikan aspirasi, gagasan, kebutuhan, kepentingan dan tuntutan.

\section{Aspirasi}

Menurut Hurlock (1980), arti aspirasi adalah keinginan yang sangat kuat yang ditandai dengan usaha untuk meraih sesuatu hal yang dipandang lebih tinggi dan lebih bernilai dari keadaan sekarang. Keinginan ini bisa berupa peningkatan status individu maupun keinginan yang bersifat extreme, terlalu berani atau tidak wajar. Aspirasi merupakan keinginan yang kuat untuk berubah dan mencapai tujuannya. Peternak awalnya memelihara sapi potong dengan cara tradisional yang saat ini beralih pada peternakan yang menggunakan teknologi modern. Keinginan peternak menjadi peternak yang maju disampaikan kepada komunitasnya. Peternak yang ingin maju dan mengubah sistem beternak yang dulu menjadi yang ada pada saat ini yaitu menggunakan teknologi modern mengantarkan peternak pada gapoktan ternak di Desa Karanganyar Kecamatan Tegalampel Kabupaten Bondowoso. Keinginan peternak untuk menjadi peternak yang maju disampaikan sebelumnya kepada kelompok ternak yang telah tergabung. Peternak sapi potong melihat pengalaman yang telah dilakukan ketua gapoktan saat ini dengan beternak secara modern peternak melihat dapat memaksimalkan hasil produksi dan panen yang lebih cepat.

Beternak secara modern yang dimaksud disini ialah menggunakan teknologi yang modern dan sistem pemeliharaannya juga modern yaitu dikandang komunal dan beternak dengan sistem timbang hidup. Keinginan peternak untuk tidak tergantung pada musim juga disampaikan oleh peternak sapi potong sehingga dengan bergabung pada gapoktan ternak peternak tidak lagi menggunaka pakan rumput akan tetapi menggunakan pakan konsentrat. Keinginan peternak tradisional beralih menjadi peternak modern karena mengalami kesulitan saat musim kemarau yang menyebabkan rerumputan menjadi kering dan sulit dicari, sehingga peternak sapi harus membeli rumput dengan harga yang cukup mahal. Tidak hanya menyampaikan keinginannya peternak juga melakukan tindakan agar keinginan yang disampaikan bisa tercapai. Kelompok ternak juga memberikan kesempatan kepada anggotanya dan mendukung anggotanya dalam menyampaikan dan mewujudkan aspirasinya.

2. Gagasan

Buah fikiran yaitu menyumbangkan ide/gagasan, pendapat, partisipasi, pengalaman untuk keberlangsungan suatu kegiatan. Wujud dari hal tersebut yaitu kehadiran saat rapat atau diskusi, adanya sumbangan pemikiran serta sebuah tanggapan seperti penolakan dalam melakukan suatu rencana ataupun program. 
Salah satu wujud pemberdayaan yaitu menyampaikan ide/ gagasan. Adanya pertemuan rutin di dalam gapoktan ternak merupakan wadah peternak dalam menyampaikan gagasan ataupun ide. Pada kesempatan tersebut para anggota gapoktan ternak di Desa Karanganyar Kecamatan Tegalampel Kabupaten Bondowoso aktif menyampaikan gagasan dalam pertemuan tersebut. Peternak yang ada dirumah sebagian besar melakukan breeding minat peternak yang instan mememunculkan salah satu ide yaitu untuk program selanjutnya mengenai breeding, pada breeding 0 sampai 10 bulan adalah proses pengawinan sampai melahirkan dan 4 bulan merupakan proses penyapihan pada gapoktan ternak akan dibuat sistem dimana didalam breeding yaitu dibagi menjadi dua tahap yaitu 7 bulan pertama proses perkawinan sampai hamil dikelola atau dipelihara oleh pihak koperasi yang ada didalam gapoktan ternak yang selanjutnya untuk 7 bulan kedepan sampai melahirkan dibeli oleh peternak yang tergabung lalu dijual kembali kepada gapoktan.

Pada pertemuan peternak bebas memberikan pendapatnya dengan syarat yaitu pendapat yang disampaikan pendapat yang positif dan membangun Adapun gagasan atau ide yang disampaikan oleh peternak terkait masalah penggemukan dan tentang program selanjutnya yaitu breeding. Gagasan lain yang disampaikan yaitu terkait masalah penggemukan yang sesingkat-singkatnya. Peternak mengharapkan panen yang lebih cepat dengan beternak menggunakan teknologi modern ini. Peternak juga berani dalam mengemukakan idenya hal ini membuktikan bahwa peternak ikut berpartisipasi dan memiliki kemajuan dalam mengutarakan ide untuk masa depan Gapoktan ternak sapi dan diri sendiri.

Pada pertemuan tersebut selain membahas tentang program kedepannya juga membahas kendala-kendala saat beternak modern ini. Dari hal tersebut dapat dilihat anggota gakpoktan ternak aktif dalam memberikan ide, salah satunya yaitu dibidang pakan saat harga jagung mulai naik peternak berinsiatif mengganti bahan menjadi kulit kopi ataupun kulit kacang dengan syarat bahan tersebut memiliki protein yang sama seperti jagung.

Gagasan atau ide yang disampaikan oleh peternak sapi tidak dibatasi oleh apapun. Pada setiap pertemuan peternak bebas memberikan idenya baik tentang program-program kedepannya ataupun insiatif-inisiatif lain terkait perkembangan ternak sapi lainnya seperti penggantian bahan konsentrat jagung menjadi kulit kacang dan kulit kopi. Peternak sapi atau anggota gapoktan ternak dapat memberikan ide yaitu peternak sapi memiliki rencana program lainnya sendiri dari peternak itu sendiri dan pada anggota gapoktan ternak diberikan ruang bebas dalam menyampaikan ide-ide sehingga peternak bukan lagi sebagai objek tapi sudah menjadi subjek di dalam gapoktan ternak.

3. Kebutuhan

Kebutuhan dalam beternak sapi potong harus dipenuhi agar beternak sapi potong dapat berjalan dengan lancar. Adapun kebutuhan beternak sapi potong yaitu yang paling utama adalah tersedianya kandang, air yang mencukupi, pakan serta obat-obatan. Hal tersebut sesuai dengan penelitian (Bank Indonesia, 2013), Kebutuhan dalam beternak sapi potong adalah air bersih, pakan, perkandangan dan obat-obatan. Kebutuhan kandang untuk setiap ekor sapi adalah seluas $2 \mathrm{~m}^{2}(0-4$ bulan) dan untuk sapi berumur 4-18 bulan 3,5m². Mesin-mesin untuk pengolahan pakan konsentrat dan peralatan pengobatan. 
Sumber Daya Alam sangat penting dalam pemenuhan kebutuhan ternak. Jenis dan ketersediaan pakan juga harus diperhatikan dalam usaha peternakan di suatu daerah. Teknologi peternakan yang sudah mulai berkembang, harus dimanfaatkan untuk menunjang pengembangan usaha peternak. Letak kandang koloni yang dikelilingi persawahan juga strategis karena dekat dengan pasar hewan yang baru serta kondisi udara yang masih jauh dari polusi dan kandang koloni yang jauh dari pemukiman warga sehingga bau dari kotoran sapi tidak mengganggu warga sekitar dengan yang dilakukan oleh Gapoktan ternak yang sudah memiliki fasilitas yang sudah mulai berkembang seperti alat pembuat konsentrat, motor roda tiga, Pickup atau mobil pengangkut ternak, alat timbang hidup. Penelitian terdahulu menyebutkan bahwa Faktor lingkungan berupa iklim berpengaruh secara langsung terhadap ternak seperti suhu, kelembaban, dan curah hujan. Fasiltas pendukung sangat membantu dalam pengembangan usaha peternakan. Sumber Daya Alam sangat penting dalam pemenuhan kebutuhan ternak.

4. Kepentingan

Kepentingan setiap individu berbeda-beda karena setiap individu memiliki kepentingan masing-masing. Dalam beternak sapi potong karena awal berdiri atas tujuan bersama jadi kepentingan yang diutamakan adalah kepentingan atas dasar bersama. Hal tersebut sesuai dengan penelitian terdahulu bahwa adanya hubungan yang erat antara individu anggota kelompoknya, lebih kecil, bersifat konkret, misalnya keluarga, teman sepermainan, dan rukun tetangga, dimana individuindividunya itu meleburkan diri secara sukarela demi kepentingan kelompoknya (semangat kebersamaan untuk berkorban demi kepentingan dan tujuan bersama.

Apabila terdapat banyak pendapat maka akan dilakukan voting. Walaupun banyak perbedaan pendapat akan tetapi gapoktan ternak memiliki solusi yaitu dengan cara melakukan voting Hal tersebut membuktikan bahwa peternak sapi memiliki kemampuan untuk mengungkapkan kepentingannya tentang sesuatu hal yang berkenaan dengan gapoktan ternak. Adapun kepentingan yang biasa disampaikan peternak yaitu tentang obat-obatan, apabila sapi sakit harus segera mendapatkan penanganan agar sapi tidak mati. Selain itu faktor kebersihan juga menjadi hal utama agar sapi tidak terserang penyakit. Pembersihan kandang dilakukan setiap hari yaitu pada pagi hari dan sore hari. Persoalan-soalan yang dihadapi secara bersama untuk kepentingan berkelompok ataupun kepentingan bersama. Peternak juga menyampaikan tentang bahan baku pakan kosentrat yang sudah mulai habis, apabila proses pembuatan pakan terhambat maka pemberian pakan pada sapi juga akan terlambat yang dapat mengganggu hasil produksi sapi.

5. Tuntutan

Tuntutan pada peternak yaitu terkait kinerja agar kegiatan didalam gapoktan dapat berjalan dengan lancar. Tugas anggota gapoktan sendiri yaitu melakukan tugasnya sesuai kesepakatan serta mengembangkan diri didalam gapoktan ternak serta menggali ilmu. Penelitian tersebut selaras dengan penelitian terdahulu, bahwa proses pemberdayaan akan berlangsung secara bertahap di lingkungan kerja, pemberdayaan akan berjalan dengan baik, dan usaha itu akan menghasilkan Sumber Daya Manusia yang bermutu, yaitu Sumber Daya Manusia yang mampu memenuhi tuntutan tugasnya dan mengembangkan dirinya sebaik-baiknya. Peternak sapi potong di gapoktan ternak sering datang terlambat sehingga mekanisme dalam pembuatan pakan sapi akan terlambat dan pemberian pakan sapi 
juga akan terlambat. Hal tersebut dapat mengganggu hasil produksi sapi potong. Peternak sapi potong di gapoktan dimiliki banyak tuntutan terhadap gapoktan ternak, hanya saja terkait masalah waktu yang sering lalai atau tidak datang tepat waktu dalam melakukan pekerjaannya sehingga mekanis di dalam kegiatan gapoktan terganggu. Perihal tersebut sudah didiskusi oleh anggota kelompok dengan penerapan pengurangan gaji atau denda agar para pengurus atau anggota disiplin dalam melaksanakan tugasnya dan agar usaha ternak sapi potong ini dapat berjalan secara berkepanjangan.

Peternak sapi potong menyampaikan apa yang menjadi keinginannya selama ini kepada komunitas terkait, penggunaan teknologi-teknologi modern dan tidak ketergantungan pada musim tentang pakan ternak. Selain menyampaikan keinginan peternak juga bertindak langsung agar keinginan yang disampaikan peternak dapat tercapai. Bergabung dengan gapoktan ternak merupakan tindakan mewujudkan keinginan peternak menjadi peternak yang maju. Selain itu peternak juga mampu memberikan ide-ide atau gagasan dalam beternak sapi potong yaitu program breeding dan pengganti pakan jagung dengan kulit kacang atau kopi. Kebutuhan beternak sapi pada umumnya yaitu kandang, air, pakan, dan obat-obatan. Peralatan lain untuk menunjang keberhasilan penggemukan sapi diperlukan mesin pembuat pakan, alat timbang hidup dan sepeda motor roda tiga. Kepentingan yang disampaikan terkait tentang beternak sapi yaitu seperti sapi sakit yang harus segera diobati, serta bahan baku konsentrat yang sudah habis. Bahan baku konsentrat yang tidak segera dipenuhi akan menghambat pembuatan pakan dan mengganggu sistem pemberian pakan. Tuntutan didalam gapoktan ternak tidak banyak hanya terkait kerja yang dilakukan peternak sapi potong. Hal tersebut sesuai dengan teori Word Bank yaitu masyarakat mampu dan diberi kesempatan dalam menyampaikan aspirasi, kebutuhan, gagasan, kepentingan serta tuntutannya.

b. Choice (Pilihan Rasional) Peternak Sapi Potong dalam Beternak Sapi Potong dan Bergabung dengan Gapoktan Ternak.

Menurut Wrihatnolo \& Dwidjowijoto (2007), teori pilihan rasional tampak jelas dalam gagasan dasarnya bahwa tindakan perseorangan mengarah pada sesuatu tujuan dan tujuan itu (dan juga tindak) ditentukan oleh nilai (preferensi). Aktor memilih tindakan yang dapat memaksimalkan kegunaan atau yang memuaskan keinginan dan kebutuhan.

Pilihan rasional yang dilakukan peternak dengan menilai keuntungan yang didapat oleh peternak selain itu pilihan rasional juga peternak memiliki tujuan dan melakukan tindakan agar tujuan tersebut bisa tercapai. Pilihan yang dipilih oleh peternak sapi potong yaitu peternak sapi potong memiliki tujuan sehingga memilih untuk berternak sapi potong dan bergabung dengan Gapoktan ternak sapi potong di Desa Karanganyar Kecamatan Tegalampel Kabupaten Bondowoso.

Tujuan peternak memelihara sapi yaitu peternak melihat prospek melihara sapi ini sangat terbuka lebar, sehingga tertarik dalam memelihara sapi dan membangun gapoktan ternak sapi. Seiring dengan bertambahnya jumlah penduduk maka kebutuhan akan daging sapi juga bertambah serta Indonesia memiliki potensi dalam pengembangan daging sapi. Penelitian tersebut selaras dengan penelitian Suryana (2017), bahwa Indonesia memiliki peluang dan potensi yang besar dalam pengembangan sapi potong. 
Lahan yang digunakan milik beberapa anggota gapoktan ternak sapi dengan status lahan hak pakai sewa dengan pembangunan kandang secara swadaya. Peternak sapi potong menyewakan lahan tersebut sebagai sebuah investasi yang dilakukan oleh peternak sapi potong yang tergabung kedalam gapoktan ternak. Pada pakan peternak gapoktan ternak menggunakan limbah-limbah pertanian yang ada melihat letak kandang di kelilingi oleh area persawahan dan juga sebagian besar mata pencaharian peternak sapi potong juga sebagai petani. Pembangunan kandang merupakan hasil swadaya masyarakat yang selanjutnya diperbaharui dengan tembok-tembok permanen. Hal tersebut selaras dengan penelitian Suryana (2017), bahwa agar pengembangan sapi potong berkelanjutan salah satu sarannya pengembangan teknologi pakan terutama pada wilayah ternak, antara lain dengan memanfaatkan limbah industri dan perkebunan.

Tujuan lain peternak bergabung untuk meningkatkan ekonomi masyarakat yaitu dengan mengubah pola pemeliharaan dari tradisional menjadi modern salah satunya dari segi pakan. Seperti hal yang sudah dijelaskan bahwa tidak mudah mengubah pola pemeliharaan tradisonal menjadi modern karena pengalaman peternak yang sudah bertahun- tahun dalam memelihara sapi diperlukan pula pengalaman lainnya bahwa beternak secara modern dapat menguntungkan dan memudahkan peternak sapi itu sendiri. Apalagi khususnya sapi potong merupakan salah satu sumber daya alam yang dapat diperbarui dan berpotensi untuk dikembangkan guna meningkatkan ekonomi masyarakat.

Salah satu keuntungan beternak sapi potong dengan cara modern yaitu panen yang cepat yaitu 3-4 bulan. Pemanenan ini lebih cepat dibandingkan dengan pola pemeliharaan biasa atau tradisonal. Pada pola tradisional sapi hanya bisa dipanen kurang lebih 1 tahun dengan biaya yang dikeluarkan yang tidak terhitung. Pada saat sapi datang peternak menimbang berat atau bobot sapi tersebut, bulan pertama peternak juga menimbang hingga masa panen. Hal tersebut dilakukan guna mengetahui penambah berat sapi yang telah dipelihara, sehingga memudahkan peternak dalam tata kelola sapi. Peternak juga dapat menghitung pengeluaran dan keuntungan yang di dapat nantinya apabila masa panen telah tiba.

Memelihara sapi dan bergabung dengan gapoktan ternak tersebut dengan pemeliharaan modern akan mendapatkan keuntungan yang banyak. Disamping keuntungan materi yang didapat peternak sapi potong juga mendapatkan ilmu dan teman yang banyak dan peternak sapi potong juga dapat memanfaatkan pengetahuan lainnya dari teman yang sudah memiliki pengalaman untuk menerima informasi-informasi terkait dengan sapi potong. Dapat dilihat dengan tujuan dan penilaian peternak yaitu memanfaatkan sekolompok dan fasilitas yang ada dengan mengakses informasi yang didapat, memanfaatkan teknologi yang ada dan dapat menemukan solusi dari kendala atau permasalahan yang ada. Penelitian tersebut selaras dengan penelitian (Amanah \& Farmayanti, 2014), bahwa power yang dimiliki, seseorang atau sekolompok orang diharapkan dapat mendayagunakan kekuatan yang dimiliki untuk mengakses informasi, teknologi, modal, mengembangkan ketrampilan dalam menemukan solusi atau masalah kehidupan.

Tindakan yang dilakukan peternak agar tujuan-tujuan tersebut dapat tercapai salah satunya yaitu melakukan kerjasama. Gapoktan ternak bekerjasama dengan BI (Bank Indonesia) pada kerjasama tersebut Bank BI membantu mencarikan modal pinjaman pada BNI dimana pinjaman tersebut atas nama anggota 
namun MOUnya pembayaran tidak dibebankan kepada anggota ternak namun pada koperasi yang memanajamen. Bunga yang diberikan BNI juga rendah yaitu sebesar $0,7 \%$ pertahun dan pembayarannya pertahun sehingga mempermudah proses pembayaran dukungan kebijakan ekonomi (finansial dan perbankan) diperlukan untuk pengembangan peternak sapi potong, karena biaya yang diperlukan untuk beternak sapi tidak sedikit, dukungan dapat berupa kemudahan prosedur perbankan kepada peternak dengan bunga yang kondusif dan kemudahan memperoleh fasilitas. Kerjasama yang dilakukan BI ialah pemberian mesin pakan, pembangunan gedung dan roda tiga.

Agar sistem di peternakan gapoktan ternak berjalan lancar pada gapoktan diberikan penerapan persyaratan yaitu penerapan persyaratan aturan sistem bagi hasil yang berbeda. Variasi yang dimaksud mencakup pembagian hasil serta pembagian biaya sarana produksi. Pembagian hasil dipotong biaya perawatan, biaya pakan, dan pengobatan dengan yang memanajamen yaitu koperasi bahwa pembagiannya sebesar $50 \%$.

Terdapat banyak hal yang menjadi tujuan peternak sapi potong dalam memelihara sapi yaitu peternak sapi potong telah lama memelihara sapi potong, penggunaan sumber daya yang dimiliki peternak yaitu lahan sebagai investasi menjadi hak pakai sewa, keuntungan yang cukup tinggi, beternak secara modern menguntungkan peternak dalam pemanenan sapi yaitu peternak dapat memanen sapi lebih cepat dari beternak menggunakan cara lama. Peternak juga menilai bahwa beternak sapi potong merupakan prospek yan bagus mengingat kebutuhan akan daging sapi di Indonesia terus bertambah. Tujuan peternak sapi potong bergabung dengan gapoktan ternak yaitu berawal dari permasalahan ketika musim kemarau tiba tanaman hijau seperti rerumputan sulit untuk ditemukan, sehingga menggunakan pakan konsentrat dapat membantu peternak tanpa bergantung dengan musim. Tujuan lainnya yaitu keinginan peternak sapi potong yang maju mengikuti perkembangan jaman, menambah ilmu-ilmu dalam beternak sapi potong secara efisien dan modern, mempermudah dalam penjualan sapi serta pakan, membuka lapangan pekerjaan untuk memenuhi kebutuhan sehari-hari, memberdayakan masyarakat serta meningkatkan perekonomian peternak sapi potong. Tujuan atau pilihan yang dilakukan peternak sapi potong berdasarkan penilaian peternak sapi potong yang dapat melihat bahwa peternak sapi potong memiliki potensi yang baik. Tindakan yang dilakukan agar tujuan tersebut tercapai yaitu melakukan kerjasama, melakukan pertemuan untuk evaluasi dan sharing. Hal tersebut sesuai dengan teori Coleman bahwa didalam pilihan peternak dapat melihat nilai yang didapat apabila berternak sapi dan bergabung dengan gapoktan ternak.

c. Kemandirian Peternak Sapi Potong

Ilmu sosial, didalamnya terdapat istilah kemandirian yang sering dipersamakan dengan istilah otonom, tidak tergantung/ bebas, mengelola diri sendiri, dan berkelanjutan diri sedangkan, suatu masyarat terdiri dari personmerson dalam tujuan bersama atas dasar pertimbangan terbentuknya kelompok baik kelompok yang terbentu atas inisiatif anggotanya maupun oleh pihak luar. Karakteristik masyarakat yang memiliki kondisi kemandirian yaitu memiliki kapasitas diri, memiliki tanggung jawab kolektif dan memiliki kemampuan berfikir dan bertindak secara berkelanjutan. 
1. Memiliki Kapasitas Diri

Kapasitas diri (personal self capacity), yaitu sikap tidak tergantumg, mampu memenuhi kebutuhan sesuai dengan potensinya, menyelesaikan masalah yang dihadapi , secara ekonomi mampu menghasilkan (produksi atau pendapatan) untuk memenuhi kebutuhan hidupnya, dan dapat melakukan kontrol dalam masyarakat. Peternak sapi potong tidak hanya beternak sapi potong saja namun, memiliki pekerjaan lain sebagai petani, memiliki toko peracangan, industri kue, dan sebagai karyawan kontrak, tidak hanya beternak para peternak sapi potong juga memiliki kegiatan lain dan kebutuhan para peternak baik kebutuhan sehari-hari maupun beternak dapat terpenuhi.

Kebutuhan saat sapi yang baru datang yaitu vitamin agar sapi tidak mengalami setres. Pertama kali sapi dipindahkan ke kandang komunal mengalami stress sehingga yang dibutuhkan dalam beternak yaitu obat-obatan seperti vitamin dan obat cacing sesuai komposisi yang sudah diketahui oleh peternak. Beternak tidak hanya obat-obatan saja yang dibutuhkan melainkan kandang yang utama, pakan, minum dan perawatan untuk sapi potong. Agar memperoleh hasil yang maksimal, terdapat beberapa hal pokok yang perlu diperhatikan dari peternak dalam pengelolaan usaha pengembangan sapi potong yaitu pemilihan bibit/bakalan, sistem penggemuka, pakan dan cara pemberiannya, penyediaan kandang, pengendalian dan pencegahan penyakit. Terpenuhinya kebutuhan dalam beternak selain dari hasil pemeliharaan sapi potong juga dari pekerjaan lainnya

Peternak sapi dapat memenuhi kebutuhan sehari-hari dan kebutuhan dalam beternak sapi selain penghasilan dari beternak sapi juga hasil dari bekerja lain seperti petani dan tenaga kerja kontrak. Kebutuhan dalam beternak sapi yaitu pakan, kandang, air, dan juga obat-obatan. Peternak sapi potong memiliki kapasitas diri secara ekonomi mampu menghasilkan dan memenuhi kebutuhan hidupnya.

2. Memiliki Tanggung Jawab Kolektif

Tanggung jawab kolektif yaitu adanya pengembangan kerjasama dan kemitraan antar warga masyarakat dalam mengatasi permasalahan dan memenuhi kebutuhan hidupnya, dan pengembangan jaringan sosial untuk mengakses berbagai peluang.

Adanya pengembangan kerjasama dan kemitraan antar warga masyarakat dalam mengatasi permasalahan dan memenuhi kebutuhan hidupnya, serta pengembangan jaringan sosial untuk mengakses berbagai peluang. Gapoktan ternak di Desa Karanganyar Kecamatan Tegalampel Kabupaten Bondowoso bekerjasama dengan Bank Indonesia juga dengan PT Bolo Semeru Farm. Kerjasama dengan PT Bolo Semeru Farm yaitu pengadaan bakalan sapi hingga pakan, selain itu PT Bolo Farm juga sebagai off taker dengan sistem dan harga yang sudah disepakati dalam ternak.

Bekerjasama dengan PT Bolo membantu dalam pemasaran yaitu sapi ambil di PT Bolo juga pakan ambil di PT Bolo. Hal tersebut membantu gapoktan dalam proses pemasaran yang awalnya terbilang sulit karena yang menggunakan sistem timbang hidup masih sedikit terutama di Bondowoso. Sesuai kesepakatan bahwa gapoktan ternak dimudahkan dalam penyediaan pakan, bakalan sapi dan juga off taker akan tetapi dalam pemanenan yang sedang dilakukan sapi mengalami keterlambatan pengangkutan sehingga hal tersebut ada diluar perjanjian. 
Gapoktan ternak juga bekerjasama deng Bank Indonesia (BI) disini yaitu sebagai classternya dari BI (Bank Indonesia), BI disini sebagai pendamping dari gapoktan ternak kegiatan yang dilakukan yaitu study banding masalah sapi, pakan, pengobatan dengan dibekali teknis yang modern. Kerjasama dengan BNI dengan gapoktan ternak terkait dengan pinjaman usaha yang persyaratannya yaitu mengatasnamakan 42 anggota karena kapasitas dikandang koloni itu 42 sapi jadi setiap sapi diatasnamakan peranggota yaitu untuk 42 ekor sapi. Penelitian tersebut sesuai dengan peneltian Sodiq \& Budiono (2012), bahwa sistem produksi peternakan sapi potong beserta rumusan strategi pengembangannya untuk peningkatan produktivitas dan aksesbilitas pembiayaan perbankan sangat dibutuhkan dalam upaya peningkatan pemberdayaan ekonomi masyarakat pedesaan.

Kerjasama antara peternak dan gapoktan yaitu pembelian pakan yang dapat dibayar ketika panen, yang dimaksud ternak diluar yaitu dimana peternak memelihara sapi ditempat masing-masing bukan dikandang komunal yang nantinya gapoktan juga berperan sebagai off taker dari peternak yang sapinya akan dijual kepada gapoktan ternak dengan sistem timbang hidup sehingga tidak ada yang dirugikan tetapi saling menguntungkan.

Peternak sapi memiliki kerjasama dengan Gapoktan ternak yaitu terkait pakan dan gaduh sapi, selain itu Gapoktan ternak juga sebagai off taker untuk peternak sapi karena harga yang diberikan transparan melalui timbang hidup dan memudahkan peternak untuk menjual sapinya. Pada Gapoktan ternak sendiri bekerjasama dengan BI sebagai pendamping peternakan secara modern juga sebagai claster gapoktan ternak sapi juga sebagai tempat peminjaman modal usaha dan PT BOLO Farm sebagai off taker dari hasil Gapoktan ternak tersebut.

3. Memiliki kemampuan berfikir dan bertindak secara keberlanjutan

Kemampuan berfikir dan bertindak secara keberlanjutan (sustainable), yaitu menjaga kualitas lingkungan sistematik dan memelihara pelayanan dan sumber daya secara berkelanjutan dan berwawasan lingkungan. Kendala yang dihadapi saat sapi sakit yaitu jika penangannya terlambat sapi akan mati, walaupun kerugian telah masuk hitungan akan tetapi gapoktan ternak selanjutnya berencana bekerjasama dengan pihak asuransi. Hal tersebut selaras dengan penelitian An-nisa et al., (2004), bahwa asuransi ternak sapi merupakan salah satu program penting untuk mendukung sektor pertanian khususnya peternakan, bagi peternak sebagai pendorong tata kelola peternakan yang baik, melindungi risiko kerugian, meningkatkan akses peternak terhadap lembaga keuangan.

Hal penting didalam adalah peternakan sarana dan prasarana harus disediakan lebih dahulu yang paling utama paling tidak dibidang pakan karena apabila sapi datang sapi harus tersedia pakannya agar tidak mengalami stress. Terkait kesehatan pihak gapoktan ternak dibantu oleh pihak kesehatan hewan. Pengadaan edukasi tentang sapi potong, dan edukasi tentang breeding. Hal tersebut selarars dengan Departemen Pertanian (2007), bahwa program breeding atau pengembangan pembibitan sapi dengan memanfaatkan potensi ternak lokal maupun silangan sangat diperlukan untuk menjamin kemandirian dalam penyediaan pejantan unggul. Peternak memiliki harapan yaitu dari hulu kehilir ditangani oleh pihak gapoktan ternak sendiri bahkan sampai pemotongan sapi sendiri. Hal tersebut menjelaskan gapoktan ternak menginginkan menjadi off taker di Bondowoso dengan sistem timbang hidup. 
Peternak menginginkan kedepannya sapi bisa sampai 500 ekor yang dipelihara, sehingga penghasilan bertambah dan hasil dari melihara sapi tersebut dibelikan sapi lagi untuk selanjutnya. Menambah jumlah sapi sama halnya menambah kandang agar jumlah sapi juga bisa bertambah akan tetapi memaksimalkan program yang sekarang sangat diperlukan agara harapan-harapan peternak bisa tercapai. Peternak sapi menginginkan kedepannya sapi di Gapoktan ternak bertambah, dari hulu ke hilir bisa lancar, ingini maju sendiri dan ingin mengajak peternak lain untu maju, memperluas kandang koloni, memiliki kerjasama dengan pihak-pihak lain juga, dengan hal ini para peternak memiliki kemampuan berpikir secara berkelanjutan agar peternak sapi potong dapat meningkatkan ekonomi sosialnya dan saling mengutungkan.

Kemandirian peternak sapi potong dapat dilihat dari pemenuhan kebutuhansehari-hari maupun kebutuhan beternak. Melakukan kerjasama dengan pihak yang dapat membantu peternak dalam pengembangan peternak sapi potong serta mampu berpikir secara berkelanjutan. Peternak sapi potong dapat memenuhi kebutuhan sehari-hari dan beternak dari hasil panen ternak sapi dan memiliki pekerjaan lain sebagai petani, karyawan kontrak, industri kue serta toko perancangan. Peternak sapi melakukan kerjasama dengan gapoktan yaitu terkait pakan yang pembelian pakan di gapoktan ternak dapat dibayar saat panen sehingga meringankan peternak dalam hal permodalan. Kerjasama yang dilakukan gapoktan ternak yaitu Bank Indonesia sebagai cluster sehingga gapoktan mendapatkan bantuan sepeda motor roda tiga, mesin pembuat pakan serta bangunan permanen. Kerjasama dengan PT Bolo Farm yaitu pengadaan bakalan, pakan dan berperan juga sebagai off taker dari hasil gapoktan ternak tersebut. Peternak juga memiliki kemampuan berpikir secara berkelanjutan, kedepannya peternak menginginkan anggota gapoktan ternak terus bertambah, menjadi off taker timbang hidup di Bondowoso, memperluas kandang koloni, dan mengharapkan peternak sapi potong dapat meningkatkan ekonomi. Kemandirian yang dilakukan peternak sesuai dengan teori Word Bank bahwa masyarakat mampu meningkatkan kemampuan dan kemandirian.

\section{SIMPULAN}

Peternak sapi potong mampu menyampaikan aspirasinya dalam beternak, kepentingan, kebutuhan, tuntutan dan memberikan ide dalam beternak sapi potong. Hal tersebut membuktikan bahwa peternak mampu dan berani dalam menyampaikan suara (voice) didalam beternak sapi potong. Choice/ pilihan rasional pilihan yang disertai nilai-nilai dan agar tujuan tersebut dapat tercapai diperlukan tindakan untuk mencapai tujuan tersebut. Adapun tujuan dari peternak sapi potong beternak sapi dan bergabung kedalam gapoktan ternak yaitu melihat prospek yang bagus kedepannya, penghasilan tambahan, panen yang lebih cepat, memberdayakan masyarakat, investasi, memperoleh banyak ilmu, persamaan visi dan misi, ingin maju dan mendapatkan keuntungan yang besar serta tindakan yang dilakukan agar tujuan tersebut tercapai yaitu melakukan kerjasama, melakukan pertemuan untuk evaluasi dan sharing, piket jaga malam untuk menjaga ternak dikandang komunal, pelaksanaan SOP pakan dan pemeliharaan agar ternak sapi terjaga dan bagi hasil yang dilakukan. Kemampuan peternak tidak tergantung pada 
musim dan bebas memilih pakan kosentrat merupakan bagian dari kemandirian. Selain itu, peternak dapat dikatakan berkelanjutan diri karena dapat melihat dan memiliki ide untuk program sapi yaitu breeding yang merupakan bagian dari kemandirian. Peternak yang mulanya merupakan person-merson karena tujuan bersama dan atas pertimbangan terbentuknya gabungan kelompk tani ternak.

Kemandirian dalam peternak sapi potong dapat dilihat dari tiga karakteristik yaitu memiliki kapasitas diri dalam hal ini peternak sapi dapat memenuhi kebutuhan sehari-hari dan kebutuhan dalam beternak sapi selain penghasilan dari beternak sapi juga hasil dari bekerja lain seperti petani dan tenaga kerja kontak. Memiliki tanggung jawab kolektif peternak sapi mampu melakukan kerjasama baik dengan pihak gapoktan maupun pihak luar. Peternak juga dapat mengatasi masalah dengan melakukan diskusi bersama peternak lainnya. Memiliki kemampuan berfikir dan bertindak secara keberlanjutan yaitu peternak di Desa Karanganyar Kecamatan Tegalampel memiliki kemampuan berpikir berkelanjutan yang kedepannya menginginkan sapi di Gapoktan ternak bertambah, dari hulu ke hilir bisa lancar, ingini maju sendiri dan ingin mengajak peternak lain untu maju, memperluas kandang koloni, memiliki kerjasam dengan pihak-pihak lain juga, dengan hal ini para peternak memiliki kemampuan berpikir secara berkelanjutan agar peternak sapi potong dapat meningkatkan ekonomi sosialnya dan saling mengutungkan.

\section{DAFTAR PUSTAKA}

Afrizal, M. A. (2014). Metode Penelitian Kualitatif: Sebuah Upaya Mendukung Penggunaan Penelitian Kualitatif Dalam Berbagai Disiplin Ilmu (Vol. 5, Issue 6). PT Raja Grafindo Persada.

Amanah, S., \& Farmayanti, N. (2014). Pemberdayaan Sosial Petani-Nelayan, Keunikan Agroekosistem, dan Daya Saing. Kerja sama antara Departemen Sains Komunikasi dan Pengembangan Masyarakat, Fakultas Ekologi Manusia, IPB dengan Yayasan Pustaka Obor Indonesia.

An-nisa, N. S., Syarief, R., \& Suprayitno, G. (2004). Strategi Pengembangan Asuransi Ternak Sapi. Jurnal Manajemen Dan Agribisnis, 12(1), 27-35. https://doi.org/10.17358/jma.12.1.27

Anggita, T. (2013). Dukungan Modal Sosial dalam Kolektivitas Usaha Tani untuk Mendukung Kinerja Produksi Pertanian Studi Kasus: Kabupaten Karawang dan Subang. Journal of Regional and City Planning, 24(3), 203-226. https://doi.org/10.5614/jpwk.2013.24.3.4

Bank Indonesia. (2013). Pola Pembiyaan Usaha Kecil Menegah Usaha Budidaya Penggemukan Sapi Potong (Vol. 148). Departemen Pengembangan akses Keuangan dan UMKM.

Departemen Pertanian. (2007). Manajemen Pengelolaan Penggemukan Sapi Potong. Balai Pengkajian Teknologi Pertanian.

Firmansyah, H. (2012). Ketercapaian Indikator Keberdayaan Masyarakat dalam Program Pemberdayaan Fakir Miskin ( P2FM ) di Kota Banjarmasin. Jurnal Agribisnis Perdesaan, 2(2), 172-180.

Hurlock, E. (1980). Psikologi Perkembangan: Suatu Pendekatan Sepanjang Rentang Kehidupan. Alih bahasa: Istiwidayati \& Soedjarwo. Edisi Kelima. In Psikologi Perkembangan. Erlangga.

Mardikanto, T., \& Soebianto, P. (2012). Pemberdayaan masyarakat dalam perspektif kebijakan publik. Alfabeta.

Mulyawan, R. (2016). Masyarakat, Wilayah, dan Pembangunan (Vol. 148). Unpad Press. 
Semiawan. (2010). Metode Penelitian Kualitatif (Vol. 5, Issue January). Grasindo.

Sodiq, A., \& Budiono, M. (2012). Produktivitas Sapi Potong pada Kelompok Tani Ternak di Pedesaan. Jurnal Agripet, 12(1), 28-33. https://doi.org/10.17969/agripet.v12i1.284

Sugiyono. (2014). Metode Penelitian Kuantitatif Kualitatif dan R\&D. Alfabeta.

Suryana. (2017). Pengembangan Usaha Ternak Sapi Potong Berorientasi Agribisnis Dengan Pola Kemitraan. Jurnal Penelitian Dan Pengembangan Pertanian, 28(1), 29-37. https://doi.org/10.21082/jp3.v28n1.2009.p29

Wrihatnolo, R. R., \& Dwidjowijoto, R. N. (2007). Manajemen Pemberdayaan, Jakarta, PT. In Elex Media Komputindo. PT Elex Media Komputindo. 